Article

\title{
Development of Durum Wheat Breads Low in Sodium Using a Natural Low-Sodium Sea Salt
}

\author{
Elena Arena ${ }^{1}\left(\mathbb{D}\right.$, Serena Muccilli ${ }^{2}$, Agata Mazzaglia ${ }^{1}$, Virgilio Giannone ${ }^{3}$, Selina Brighina ${ }^{1}$, \\ Paolo Rapisarda ${ }^{2}$, Biagio Fallico ${ }^{1}$ D, Maria Allegra ${ }^{2}$ (D) and Alfio Spina ${ }^{4, *(D)}$ \\ 1 Di3A-Dipartimento di Agricoltura, Alimentazione e Ambiente, University of Catania, via S. Sofia 100, \\ 95123 Catania, Italy; earena@unict.it (E.A.); agata.mazzaglia@unict.it (A.M.); selina.brighina@unict.it (S.B.); \\ bfallico@unict.it (B.F.) \\ 2 CREA-Consiglio per la ricerca in agricoltura e l'analisi dell'economia agraria, Centro di Ricerca \\ Olivicoltura, Frutticoltura e Agrumicoltura, Corso Savoia 190, 95024 Acireale (Catania), Italy; \\ serenamuccilli@hotmail.com (S.M.); paolo.rapisarda@crea.gov.it (P.R.); maria.allegra@crea.gov.it (M.A.) \\ 3 DSAAF-Dipartimento di Scienze Agrarie, Alimentari e Forestali, University of Palermo, Viale delle Scienze, \\ Ed. 4, 90128 Palermo, Italy; virgiliogiannone@hotmail.com \\ 4 CREA - Consiglio per la ricerca in agricoltura e l'analisi dell'economia agraria, Centro di Ricerca \\ Cerealicoltura e Colture Industriali, Corso Savoia 190, 95024 Acireale (Catania), Italy \\ * Correspondence: alfio.spina@crea.gov.it
}

Received: 11 May 2020; Accepted: 4 June 2020; Published: 5 June 2020

\begin{abstract}
Durum wheat is widespread in the Mediterranean area, mainly in southern Italy, where traditional durum wheat breadmaking is consolidated. Bread is often prepared by adding a lot of salt to the dough. However, evidence suggests that excessive salt in a diet is a disease risk factor. The aim of this work is to study the effect of a natural low-sodium sea salt (Saltwell ${ }^{\circledR}$ ) on bread-quality parameters and shelf-life. Bread samples were prepared using different levels of traditional sea salt and Saltwell ${ }^{\circledR}$. The loaves were packaged in modified atmosphere conditions (MAPs) and monitored over 90 days of storage. No significant differences $(p \leq 0.05)$ were found in specific volumes and bread yield between the breads and over storage times, regardless of the type and quantity of salt used. Textural data, however, showed some significant differences $(p \leq 0.01)$ between the breads and storage times. 5-hydroxymethylfurfural (HMF) is considered, nowadays, as an emerging ubiquitous processing contaminant; bread with the lowest level of Saltwell ${ }^{\circledR}$ had the lowest HMF content, and during storage, a decrease content was highlighted. Sensory data showed that the loaves had a similar rating $(p \leq 0.05)$ and differed only in salt content before storage. This study has found that durum wheat bread can make a nutritional claim of being "low in sodium" and "very low in sodium".
\end{abstract}

Keywords: Triticum turgidum L. subsp. durum Desf.; bread; $\mathrm{NaCl}$; low-sodium sea salt; $\mathrm{Na}^{+}$reduction; physico-chemical and textural attributes; sensory evaluation

\section{Introduction}

There is much evidence suggesting that excessive salt intake endangers our health [1-3], and reducing its consumption is one of the first steps to preventing noncommunicable diseases [4]. Dietary habits are often developed during childhood [5-7], so nutritional education towards a low-sodium diet with adequate potassium intake should be encouraged [8,9]. In Italy, salt consumption by children and adolescents suggests that the average daily sodium consumption exceeds the official recommendations [10].

Natural foods contain modest amounts of sodium [11], and approximately two-thirds of salt intake come from its addition during food preparation [12]. Eighty food categories were identified 
as significant contributors to salt intake, and targets were set for the food industry to meet in each category within a certain period [13].

The WHO member states have agreed to reduce the global population's intake of salt by a relative $30 \%$ by 2025 , and several strategies have been undertaken to improve the consumer's understanding of healthy eating recommendations [14-19].

Nutrition claims of "low sodium/salt", "very low sodium/salt", and "sodium/salt-free" for foods containing 1.2, 0.4 , and $0.05 \mathrm{~g} \mathrm{~kg}^{-1}$ of sodium, respectively, (or the equivalent value for salt) on food labels, informs consumers about salt content [20-22].

Salt is an essential ingredient in breadmaking: it retards gas production, enhances bread flavor, affects the rheological properties of dough, controls fermentation (decreasing yeast activity in the dough), and it can affect the quality parameters of bread [23,24]. Furthermore, $\mathrm{NaCl}$ has a strengthening effect on gluten, increasing its resistance or elasticity, and decreasing the extensibility of the dough $[25,26]$.

The strategies to reduce sodium in bread include the use of reduced-sodium sea salt [27], the partial replacement of sodium chloride with potassium chloride and yeast extract [28], the use of a salt substitute with $57 \%$ of sodium chloride [29], and heterogeneous $\mathrm{NaCl}$ distribution, leading to enhanced saltiness by taste contrast [30].

In bread wheat (Triticum aestivum L.), salt is generally used at levels of about $1-2 \%$ based on flour weight [31]. A survey of salt content in artisan and industrial bread produced in all Italian regions was conducted in 2009/2010, its data having been recently published [32]. Artisan breads contained between $0.7 \%$ and $2.3 \% \mathrm{~g} / 100 \mathrm{~g}$ of salt, while industrial bread, on average, contained $1.6 \%$ salt, most samples (56\%) having a very high content. In the Mediterranean area, the cultivation of durum wheat (Triticum turgidum L. subsp. durum Desf.) is widespread compared to that of bread wheat [33] as it has a greater tolerance to drought, high temperatures, and fungal diseases, but less resistance to winter and spring cold. According to traditional uses, mainly in Southern Italy, bread is prepared from remilled durum wheat semolina [34]. Durum wheat milling products are characterized by peculiar chemical, rheological, colorimetric, and baking properties [35-39]. The bread has a compact texture, being in some cases excessively dense, with lower specific volume and harder crumbs than white bread [39], and the characteristic taste and flavor are generally enhanced by adding a high percentage of salt, from 20 to $25 \mathrm{~g} \mathrm{~kg}^{-1}$ [28].

In the last few years, the use of low-sodium salts in foods has been recommended.

However, almost all the commercially available low-sodium salts are produced by blending purified potassium chloride with ordinary table salts to achieve a reduced sodium content.

Natural low-sodium sea salt not only provides less sodium and does not affect the taste profile, but contains lots of essential trace minerals such as magnesium, potassium, calcium, and other nutrients the body requires.

Therefore, the aim of this paper is to evaluate the effect of substituting salt with low-sodium sea salt to measure the quality parameters of durum wheat bread over long storage.

\section{Materials and Methods}

\subsection{Materials}

Durum wheat (Triticum turgidum L. subsp. durum Desf.) remilled semolina for breadmaking [39] was provided by "Valle del Dittaino Società Cooperativa Agricola" (Assoro, Italy), an industrial bakery with a durum wheat mill.

The bread ingredients were food grade. Compressed yeast (AB Mauri, Casteggio, Italy) and traditional sea salt $(99.5 \% \mathrm{NaCl}$; Mulino S. Giuseppe, Catenanuova, Italy) employed in the breadmaking process were purchased in a local retailer. Saltwell ${ }^{\circledR}$ (Salinity Group, Saltwell AB Göteborg Sweden) is a natural low-sodium sea salt (less than $35 \%$ ) extracted from an underground sea below the Atacama desert (Chile). This natural sea salt contains $65 \pm 1 \% \mathrm{NaCl}, 30 \pm 1.5 \% \mathrm{KCl}, 1.0 \pm 0.1 \%$ of 
$\mathrm{MgSO}_{4}, 0.5 \pm 0.1 \%$ of $\mathrm{CaSO}_{4}$, and traces of other salts and minerals. Saltwell ${ }^{\circledR}$ was kindly donated by Medsalt-Mediterranean Salt Company S.r.l. (Rome, Italy).

Various levels $\left(1.70 \%, 0.35 \%, 0.15 \%\right.$ on semolina basis) of traditional sea salt and Saltwell ${ }^{\circledR}$ were used in dough formulations, as listed in Table 1.

Table 1. Bread type code and percentage of two salts on remilled semolina basis.

\begin{tabular}{cc}
\hline Bread Types Code & Salt Added $(\% w / w$ Remilled Semolina) \\
\hline Control A & $1.70 \%$ Traditional sea salt \\
Control B & $1.70 \%$ Saltwell \\
1A & $0.35 \%$ Traditional sea salt \\
1B & $0.35 \%$ Saltwell ${ }^{\circledR}$ \\
2A & $0.15 \%$ Traditional sea salt \\
2B & $0.15 \%$ Saltwell \\
\end{tabular}

\subsection{Methods}

\subsubsection{Physico-Chemical and Rheological Analyses of Remilled Semolina}

The physico-chemical analyses of remilled semolina were carried out following the methods indicated by Giannone et al. (2018) and Palumbo et al. (2002) [39-41]: moisture content was determined according to the AACC 08-01 method (AACC, 2000) [42]. Protein content was determined by means of the Infratec 1241 Grain Analyzer (Foss Tecator, Höganäs, Sweden), based on near infrared transmittance. Ash content was determined according to the AACC 44-19 method (AACC, 2000) [42]. The particle size distribution was determined by a LabSifter (KBF7SN, Buhler, Switzerland). Remilled semolina for breadmaking was sieved for exactly 5 min on sieves with openings of 300, 200, 180, and $160 \mu \mathrm{m}$. Wet and dry gluten and gluten index were obtained by using a Glutomatic System (Glutomatic 2200, Centrifuge 2015, Glutork 2020; Perten Instruments AB, Huddinge, Sweden), according to the UNI 10690 method (UNI, 1979) [43]. The $\alpha$-amylase activity was obtained by using the Falling Number 1500 apparatus (Perten Instruments AB, Huddinge, Sweden), according to the ISO 3093:2009 method (ISO, 2009) [44].

The CIELAB color parameters $\left(L^{*}, a^{*}, b^{*}\right)$ were determined by Chromameter CR-300 (Minolta, Osaka, Japan), using the illuminant $\mathrm{D}_{65}$. Alveograph indices were determined according to the AACC method 54-30A (AACC, 2000) [42] using an alveograph model MA 87 equipped with the software Alveolink NG (Tripette et Renaud, Villeneuve-la-Garenne, France). Farinograph parameters were obtained according to the AACC 54-21 method (AACC, 2000) [42] using a Farinograph, equipped with the software Farinograph ${ }^{\circledR}$ (Brabender instrument, Duisburg, Germany).

\subsubsection{Bread Sample Production and Packaging}

Bread samples were produced in a local breadmaking company ("Valle del Dittaino Società Cooperativa Agricola", Assoro, Italy), according to a proven industrial formulation: remilled durum wheat semolina $(65 \mathrm{~kg})$, compressed yeast $(0.9 \%$ on semolina basis), water ( $66.0 \%$ on semolina basis) and the corresponding amount of salt. Six bread formulations containing different levels of traditional sea salt and low-sodium sea salt were produced (Table 1). The dough was mixed for $17 \mathrm{~min}$ in a high-speed mixer (San Cassiano, Italy). The final dough temperature was $26 \pm 1^{\circ} \mathrm{C}$. The dough was left to rest in bulk for $15 \mathrm{~min}$, divided into $980 \pm 20 \mathrm{~g}$ portions (100 loaves for each production), proofed for $150 \mathrm{~min}$ at $32 \pm 1{ }^{\circ} \mathrm{C}$ and $66 \pm 2 \%$ relative humidity (RH) and baked at $220^{\circ} \mathrm{C}$ for $60 \mathrm{~min}$, in industrial tunnel ovens measuring $33 \times 3 \mathrm{~m}$ (Pavailler Engineering, Galliate, Italy). The baked loaves, with an approximate weight of $1 \mathrm{~kg}$ each, were automatically transported to a cooling chamber (Tecnopool, Italy) set at $20 \pm 2{ }^{\circ} \mathrm{C}$ for $120 \mathrm{~min}$. After cooling, the loaves were sliced by means of an automatic slicing machine (Brevetti Gasparin, Marano Vicentino, Italy) to $11 \pm 1 \mathrm{~mm}$ thickness. About $450 \mathrm{~g}$ of sliced bread per loaf was packaged under modified atmosphere conditions (MAPs) using inert gas 
(70:30 $\mathrm{N}_{2}: \mathrm{CO}_{2}$ ). The bread packaging materials consisted of two plastic films provided by Cryovac Sealed Air (Elmwood Park, NJ, USA).

The samples were stored for up to 90 days at $20 \pm 2{ }^{\circ} \mathrm{C}$ and $60 \pm 2 \% \mathrm{RH}$. The quality parameters were determined at regular intervals in triplicate for each batch.

The following parameters and properties were tested for each bread sample during each sampling: volume, height, weight, diameter basis, crumb porosity, internal structure, top and base crust thickness, texture profile analysis, water activity, moisture, $\mathrm{pH}$, 5-hydroxymethylfurfural (HMF) content, crust and crumb color, and sensory evaluation.

\subsubsection{Bread Quality Evaluation}

Determination of the Physico-Chemical Properties of the Breads

The volume was determined in a loaf volume meter by measuring the volume of rapeseed displaced by the bread, according to the AACC method 10.05.01 (AACC, 2000) [42]. The specific volume $(\mathrm{mL} / \mathrm{g})$ was calculated as a ratio of the loaf volume and the bread weight. The specific weight was calculated as the ratio of the loaf weight and bread volume. The $\mathrm{h} / \mathrm{d}$ ratio was obtained as the ratio of the bread height and bread diameter of the loaf base. The crumb porosity was estimated using the Mohs scale. The CIELAB space $L^{*} a^{*} b^{*}$ color parameters were measured for the crumb, in the transversely cut bread, and on the crust surface, averaging ten distinct points in each case, using a chromameter (CR-200, Konica Minolta, Osaka, Japan) with illuminant $\mathrm{D}_{65}$.

Bread samples were analyzed for $\mathrm{Na}^{+}\left(\mathrm{mg} \mathrm{Kg}^{-1}\right)$ content by inductively coupled plasma optical emission spectrometry (ICP-OES Optima 2000DV, Perkin Elmer, Italy). The samples were first ground to a powder, and oven-dried at $105{ }^{\circ} \mathrm{C}$ for $4 \mathrm{~h}$ until constant weight, then an aliquot equal to $0.5 \mathrm{~g}$ was weighed and placed in a muffle furnace at $600^{\circ} \mathrm{C}$ for $12 \mathrm{~h}$. After mineralization, the ashes were dissolved in $4 \mathrm{~mL}$ of distilled water and $0.5 \mathrm{~mL}$ of nitric acid at $69.5 \%$ (Superpure; Merck, Darmastadt, Germany). The solutions were poured into $50 \mathrm{~mL}$ flasks and brought to volume with distilled water before the analyses.

Water activity $\left(\mathrm{a}_{\mathrm{W}}\right)$ was determined by a Hygropalm $40 \mathrm{AW}$ (Rotronic Instruments Ltd., Crawley, UK) according to the manufacturer's instructions. Three bread slices (11 $\pm 1 \mathrm{~mm}$ thickness) were used, after removal of the crust. For each set of determinations, separate loaves were used.

The moisture content of bread crumb was determined by oven drying at $105^{\circ} \mathrm{C}$ until constant weight, according to AOAC method no. 945.15 [45]. The $\mathrm{pH}$ was measured according to [46] using a $\mathrm{pH}$ meter (Mettler Toledo, MP 220).

\subsection{Texture Profile Analysis of Breads}

The texture profile analysis (TPA) of bread was determined using a Universal testing machine (model 3344, Instron, Norwood, MA, USA.) equipped with a cylindrical probe of $50 \mathrm{~mm}$ of diameter and a $2000 \mathrm{~N}$ load cell. Data were acquired through Bluehill ${ }^{\circledR} 2$ software (Instron, Norwood, MA, USA). Cyclic compression tests (a 30-s gap between first and second compression) were set up: the crosshead speed was $3.3 \mathrm{~mm} / \mathrm{s}$, the force required to compress the samples by $40 \%$ was recorded on $5-\mathrm{cm}$ side square portions of $24-\mathrm{mm}$ thick slices, and the average value of five replicates was taken. The TPA profile recorded four primary parameters: hardness $(\mathrm{N})$, springiness $(\mathrm{mm})$, resilience, gumminess, and one derived parameters (chewiness, $\mathrm{N} \mathrm{mm}$ ).

\subsection{HMF Extraction and HPLC Analysis}

HMF was extracted and determined following the methodology proposed by [28]. Ground bread samples (5 g; La Moulinette, Moulinex, 2002) and $25 \mathrm{~mL}$ of water (J.T. Baker, Deventer, Holland) were put into a volumetric flask $(50 \mathrm{~mL})$ and stirred for $10 \mathrm{~min}$. Then the sample was diluted up to $50 \mathrm{~mL}$ with water (JT. Baker, Deventer, Holland) and centrifuged for $45 \mathrm{~min}$ at $5000 \mathrm{rpm}$. An aliquot of the supernatant was filtered through a $0.45-\mu \mathrm{m}$ filter (Albet) and injected into an HPLC system (Shimadzu 
Class VP LC-10ADvp) equipped with a DAD (Shimadzu SPD-M10Avp). The column was a Gemini NX $\mathrm{C} 18(150 \times 4.6 \mathrm{~mm}, 5 \mu \mathrm{m}$; Phenomenex $)$ fitted with a guard cartridge packed with the same stationary phase. The HPLC conditions were the following: isocratic mobile phase, $90 \%$ water (J.T. Baker) at $1 \%$ acetic acid (Merck), and 10\% methanol (Merck); flow rate, $0.7 \mathrm{~mL} / \mathrm{min}$; injection volume, $20 \mu \mathrm{L}$. The wavelength range was $220-660 \mathrm{~nm}$, and the chromatograms were monitored at $283 \mathrm{~nm}$. HMF was identified by splitting the peak of the HMF from the bread-solution sample with a standard of HMF ( $p>98 \%$ Sigma-Aldrich, St. Louis, MO, USA) and by comparing the UV spectra of the HMF standard with that of the bread samples. All analyses were performed in duplicate, including the extraction procedure, and the reported HMF concentration was, therefore, the average of four values. The results were expressed as mg of HMF per kilogram of dry matter.

\subsection{Sensory Evaluation}

The sensory profile $[28,47]$ was defined by a trained [48] panel of 12 judges (six females and six males, 28-40 years old). The judges, recruited for their individual abilities, had more than five years of experience in the sensory analysis of bread and bakery products, and they were submitted to further training over 4 weeks to generate attributes using handmade and industrial breads and to familiarize themselves with the scales and procedures. The judges, using a discontinuous scale between 1 (absence of the sensation) and 9 (extremely intense), have evaluated the intensity of the 11 sensory attributes selected on the basis of frequency $(\geq 60 \%)$, following the definitions given by [49-51] (Table 2 ).

Table 2. Descriptive terms used for sensory profiling of bread.

\begin{tabular}{|c|c|c|c|c|}
\hline \multirow{2}{*}{ Crumb appearance } & \multirow{2}{*}{$\begin{array}{c}\text { Attributes } \\
\text { Crumb color } \\
\text { Alveolar structure }\end{array}$} & \multirow{2}{*}{$\begin{array}{c}\text { Definition } \\
\text { Color intensity of crumb } \\
\text { Porosity of crumb }\end{array}$} & \multicolumn{2}{|c|}{ Scale Anchors } \\
\hline & & & Fine and uniform & $\begin{array}{l}\text { Coarse and poorly } \\
\text { homogeneous }\end{array}$ \\
\hline \multirow[t]{2}{*}{ Visual-tactile } & Elasticity & $\begin{array}{l}\text { Ability of the crumb to recover from } \\
\text { compression exerted by fingers }\end{array}$ & $\begin{array}{l}\text { Slow and } \\
\text { partial recovery }\end{array}$ & $\begin{array}{c}\text { Fast and } \\
\text { complete recovery }\end{array}$ \\
\hline & Humidity & $\begin{array}{l}\text { Humidity perceived at the surface of } \\
\text { bread crumb }\end{array}$ & Dry & Humid \\
\hline \multirow{3}{*}{ Aroma/Flavor } & Bread & $\begin{array}{l}\text { The typical aroma/flavor of bread just } \\
\text { taken out of the oven }\end{array}$ & Weak & Strong \\
\hline & Yeasty & $\begin{array}{l}\text { The aroma/flavor of a } \\
\text { fermented yeast-like }\end{array}$ & None & Strong \\
\hline & Wheat & $\begin{array}{l}\text { The typical aroma/flavor of wheat } \\
\text { Aroma/Flavor unpleasant, not }\end{array}$ & None & Strong \\
\hline \multirow{4}{*}{ Taste } & Sweet & $\begin{array}{c}\text { A basic taste factor produced } \\
\text { by sugars }\end{array}$ & None & Strong \\
\hline & Salty & $\begin{array}{c}\text { A basic taste factor produced by } \\
\text { sodium chloride }\end{array}$ & None & Strong \\
\hline & Sour & A basic taste factor produced by acids & None & Strong \\
\hline & Bitter & $\begin{array}{l}\text { A basic taste factor produced } \\
\text { by caffeine }\end{array}$ & None & Strong \\
\hline Mouthfeel & Astringent & $\begin{array}{l}\text { Sensory perception in the oral cavity } \\
\text { that may include drying sensation } \\
\text { and roughing of the oral tissue }\end{array}$ & None & Strong \\
\hline
\end{tabular}

The evaluation sessions, performed at $0,15,30,60$, and 90 days of storage, were conducted in the sensory laboratory [52] of Di3A (University of Catania, Italy) from 11:00 a.m. to 12:00 a.m. in individual booths illuminated with white light. The sliced bread samples were served on plates, coded with three-digit numbers, and water was provided to judges for rinsing between samples. The order 
presentation was randomized among judges and sessions using a randomized complete block. All data were acquired by a direct computerized registration system (FIZZ Biosystems. ver. $2.00 \mathrm{M}$, Couternon, France).

\subsection{Statistical Analysis}

The statistical analysis was performed using the Statgraphics ${ }^{\circledR}$ Centurion XVI software package (Statpoint Technologies, INC.). A two-way analysis of variance (ANOVA), followed by Tukey's HSD test $(p \leq 0.001 ; p \leq 0.01 ; p \leq 0.05)$, was carried out on physico-chemical and textural attributes. The data were expressed as means \pm standard deviations. The sensory data for each attribute were submitted to one-way ANOVA. The significance was tested by means of the F-test. A principal component analysis (PCA) was performed using PAST, Paleontological Statistics software package, 2011 [53].

\section{Results and Discussion}

\subsection{Physico-Chemical and Rheological Characterization of the Durum Wheat Remilled Semolina}

Physico-chemical characteristics of remilled semolina were moisture $13.8 \pm 0.07 \mathrm{~g} / 100 \mathrm{~g}$, protein $12.2 \pm 0.10 \mathrm{~g} / 100 \mathrm{~g}$, and ash $0.87 \pm 0.01 \mathrm{~g} / 100 \mathrm{~g}$. These quality parameters met the Italian legal requirements [54]. Particle size distribution was $>300 \mu \mathrm{m}$ : $11.0 \pm 1.73 \mathrm{~g} / 100 \mathrm{~g}$; between $200-300 \mu \mathrm{m}$ :

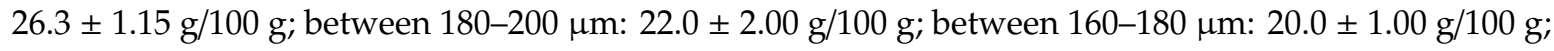
$<160 \mu \mathrm{m}: 20.7 \pm 4.04 \mathrm{~g} / 100 \mathrm{~g}$. These findings agreed with those reported by other authors for remilled semolina [39]. Dry gluten content was $10.0 \pm 0.1 \mathrm{~g} / 100 \mathrm{~g}$. The gluten index value was $80.7 \pm 4.0$, and the value of amylase activity at the falling number was low (577 $\pm 3.0 \mathrm{~s})$. Regarding dry gluten content and relative qualitative index, the sample exhibited regular gluten quantities and high gluten tenacity. Similar values were reported by $[28,39,55]$.

As regards color parameters, the values were lightness $\left(L^{*}\right) 71.0 \pm 0.3$, red index $\left(a^{*}\right) 2.12 \pm 0.02$, yellow index $\left(b^{*}\right) 18.52 \pm 0.05$.

Rheological behavior was ev ergy (W) was $209 \pm 410^{-4} \times \mathrm{J}$, while the tenacity/extensibility (P/L) value showed a tenacious dough (value $=2.5$ ). Strong gluten is expected in remilled durum wheat semolina [24].

Mixing behavior was evaluated by a farinograph apparatus. The semolina sample indicated the quantity of water absorbed at $500 \mathrm{BU}$ (Brabender Unit), and the dough consistency was $60.6 \pm 0.04 \%$ due to high protein content. The values of dough development time ( $1 \mathrm{~min}, 48 \mathrm{~s} \pm 3.0 \mathrm{~s}$ ), dough stability ( $4 \mathrm{~min} \pm 12 \mathrm{~s})$, and softening index $(58 \pm 1 \mathrm{BU})$ agreed with those reported by other authors on remilled semolina $[28,38,39,55]$.

\subsection{Sodium Content in Bread}

The levels of the two salts used in the loaves, the sodium content, and the minimum limits established by EU regulations [20,21] applying to nutritional claims are shown in Table 3.

Table 3. Percentage of two salts in bread, sodium content and limits established by EU regulations [21,22] (data are means \pm standard deviations).

\begin{tabular}{|c|c|c|c|}
\hline Type & $\begin{array}{l}\text { Salt in Experimental } \\
\text { Bread }(\%)\end{array}$ & $\mathrm{Na}^{+}$Content $(\mathrm{g} / 100 \mathrm{~g})$ & $\begin{array}{l}\text { Regulations (EU) No. 1924/2006 } \\
\text { and No. 1047/2012-Nutritional Claims }\end{array}$ \\
\hline Control A & $1.22 \%$ Traditional sea salt & $0.430 \pm 0.014 \mathrm{~A}$ & - \\
\hline Control B & $1.22 \%$ Saltwell ${ }^{\circledR}$ & $0.240 \pm 0.014 \mathrm{~B}$ & - \\
\hline $1 \mathrm{~A}$ & $0.25 \%$ Traditional sea salt & $0.087 \pm 0.001 C$ & $0.12 \mathrm{~g}$ of $\mathrm{Na}^{+}$-low in sodium \\
\hline $1 \mathrm{~B}$ & $0.25 \%$ Saltwell ${ }^{\circledR}$ & $0.064 \pm 0.001 C$ & $0.12 \mathrm{~g}$ of $\mathrm{Na}^{+}$-low in sodium \\
\hline $2 \mathrm{~A}$ & $0.11 \%$ Traditional sea salt & $0.048 \pm 0.001 C$ & - \\
\hline $2 \mathrm{~B}$ & $0.11 \%$ Saltwell ${ }^{\circledR}$ & $0.035 \pm 0.000 \mathrm{C}$ & $0.04 \mathrm{~g}$ of $\mathrm{Na}^{+}$- very low in sodium \\
\hline
\end{tabular}

Different capital letters in the same column indicate significant difference $(p \leq 0.001)$. 


\subsection{The Quality Parameters of Breads and Their Evolution during Storage}

The $p$-values for all the physical and textural parameters of the bread types with respect to storage time are reported in Table 4.

The specific volumes and weights of the loaves were significant for each of the two factors of variability (type (A), storage time (B), and their interaction $(\mathrm{A} \times \mathrm{B})$, even with different $p$ levels $(p \leq 0.001$ for storage time, $p \leq 0.01 \mathrm{~A} \times \mathrm{B}$ interaction, and $p \leq 0.05$ per type; see Table 4 ).

The results of the physical and textural properties of the industrial breads in the MAP conditions during 90 days of storage are shown in Tables 5 and 6 .

No significant differences in specific volumes were shown among the bread samples, regardless of the type and level of sea salt (Table 4).

These findings agree with those reported by [23], but they disagree with those reported by [24]. Additionally, no significant differences in specific weight were observed among the controls and other bread samples or during storage time. The addition of different types and quantities of sea salt did not decrease bread yield. After 60 days of storage, the specific weight decreased.

The ratio between the height and diameter of the loaves used in the baking industry to parametrize possible dough failure was significant $(p \leq 0.001)$ for all the factors and their interaction (Table 4$)$. At time 0 , control A was found to have the greatest $\mathrm{h} / \mathrm{d}$ ratio (approximately 4.5 ) due to the addition of ordinary sea salt (Table 5). The other bread samples, as expected, showed a lower ratio during storage, especially the bread samples containing less traditional sea salt and sea salt with reduced $\mathrm{Na}^{+}$. These findings agree with those reported by [28].

Significant differences were found for loaf porosity among the types $(p \leq 0.001)$ and the $\mathrm{A} \times \mathrm{B}$ interaction $(p \leq 0.05)$, but not for storage time (B) (Table 4). After baking (t0), almost all the types, except for $2 \mathrm{~B}$, showed proper development of crumb porosity. Starting from 15 days of storage, the performance of $2 \mathrm{~A}$ also slightly decreased (Table 5).

Significant differences were found between the types $(p \leq 0.001)$ and storage times $(p \leq 0.01$ and $p \leq 0.001$, respectively) but not for $\mathrm{A} \times \mathrm{B}$ interaction as regards internal structure and top crust thickness (Table 4). As for internal structure, only control A had an irregular structure over the whole storage time. Similar results were reported by [28].

As for top crust thickness, for up to 30 days of storage, no remarkable differences were recorded among the types (mean value of $3.8 \mathrm{~mm}$ ); after 60 days, the values decreased up to $2.67 \mathrm{~mm}$ for control B.

No significant difference was highlighted for basis crust thickness between the types, the different storage times, and their interactions (Table 4). Almost all the bread samples exhibited a mean value of basis crust thickness of $4 \mathrm{~mm}$. These findings agree with those reported by [28].

Three of the five parameters of texture profile analysis (hardness, gumminess, and chewiness) were always significant $(p \leq 0.001)$, while resilience and springiness were significant per type and storage time $(p \leq 0.001)$, but not for $\mathrm{A} \times \mathrm{B}$ interaction (Table 4$)$. The two control breads (1A and $1 \mathrm{~B})$, as expected, showed lower values for the first three parameters. Starch retrogradation (i.e., the recrystallization of polysaccharide in gelatinized starch) is believed to be the main cause of crumb firmness change during storage [56].

Textural data highlighted high values of hardness, with significant differences among the samples, as reported by [39], and storage time (Table 6).

The hardness values, as expected, increased as the storage period progressed. As regards the bread samples, control A reported the lowest values during the entire storage period. Up to t30, the two controls, albeit with statistically different values, recorded the lowest hardness values. From t60, the control A values remained low, while the control B values increased until reaching about $55 \mathrm{~N}$ at the end of storage. 
Table 4. Analysis of variance of the physical and textural parameters studied on the loaves ( $p$-values).

\begin{tabular}{|c|c|c|c|c|c|c|c|c|c|c|c|c|c|}
\hline $\begin{array}{l}\text { Factors of } \\
\text { Variability }\end{array}$ & $\begin{array}{l}\text { Degrees of } \\
\text { Freedom }\end{array}$ & $\begin{array}{l}\text { Specific } \\
\text { Volume }\end{array}$ & $\begin{array}{l}\text { Specific } \\
\text { Weight }\end{array}$ & h/d Ratio & Porosity & $\begin{array}{l}\text { Internal } \\
\text { Structure }\end{array}$ & $\begin{array}{l}\text { Top Crust } \\
\text { Thickness }\end{array}$ & $\begin{array}{l}\text { Basis Crust } \\
\text { Thickness }\end{array}$ & Hardness & Springiness & Resilience & Gumminess & Chewiness \\
\hline Type (A) & 5 & 0.002 & 0.014 & 0.000 & 0.000 & 0.000 & 0.000 & 0.444 & 0.000 & 0.000 & 0.000 & 0.000 & 0.000 \\
\hline Storage time (B) & 4 & 0.000 & 0.000 & 0.000 & 0.156 & 0.007 & 0.000 & 0.571 & 0.000 & 0.000 & 0.000 & 0.000 & 0.000 \\
\hline $\mathrm{A} \times \mathrm{B}$ & 20 & 0.011 & 0.008 & 0.000 & 0.021 & 0.824 & 0.064 & 0.568 & 0.000 & 0.529 & 0.088 & 0.000 & 0.000 \\
\hline
\end{tabular}

Table 5. Evaluation of physical properties during storage of the bread samples produced using different types and levels of sea salt (data are means \pm standard deviations).

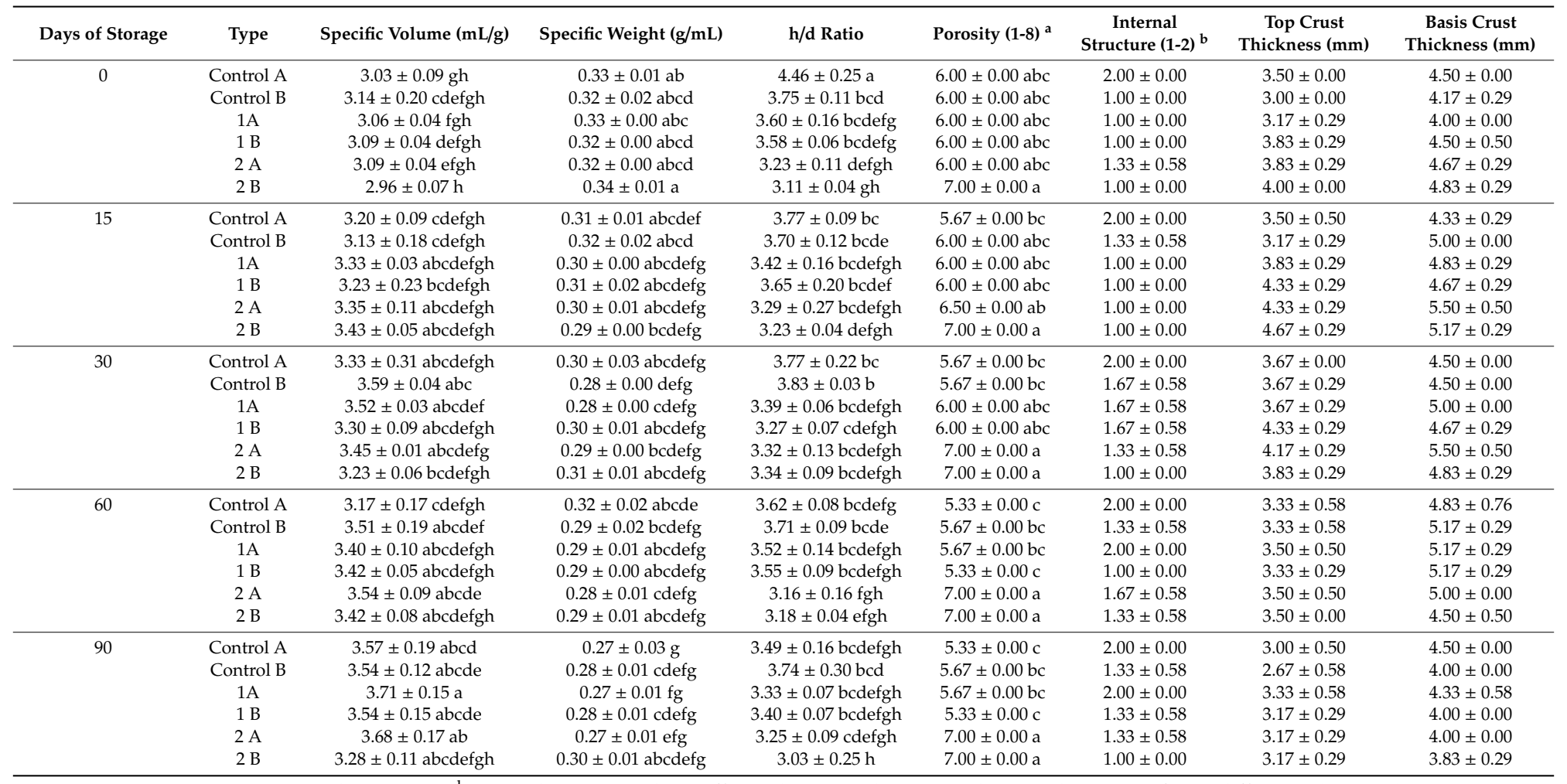

${ }^{a} 1$, most porous; 8 , least porous. ${ }^{b} 1$, regular; 2 , irregular. Different letters in the same column indicate significant difference $(p \leq 0.01)$. 
Table 6. Evaluation of textural parameters of bread samples produced using different types and levels of sea salt during storage (data are means \pm standard deviations).

\begin{tabular}{|c|c|c|c|c|c|c|}
\hline Days of Storage & Type & Hardness (N) & Springiness $\mathrm{mm}$ ) & Resilience & Gumminess & Chewiness $(\mathbf{N} \times \mathbf{m m})$ \\
\hline \multirow[t]{6}{*}{0} & Control A & $10.57 \pm 0.43 \mathrm{o}$ & $5.10 \pm 0.60$ & $0.91 \pm 0.02$ & $9.58 \pm 0.31 \mathrm{q}$ & $50.36 \pm 2.94 \mathrm{o}$ \\
\hline & Control B & $16.97 \pm 0.68 \mathrm{mn}$ & $4.76 \pm 0.46$ & $0.91 \pm 0.01$ & $10.26 \pm 0.58 \mathrm{pq}$ & $52.44 \pm 4.99 \mathrm{o}$ \\
\hline & $1 \mathrm{~A}$ & $28.11 \pm 0.63 \mathrm{jkl}$ & $5.32 \pm 0.10$ & $0.85 \pm 0.01$ & $20.14 \pm 0.32 \mathrm{mno}$ & $108.70 \pm 0.90 \mathrm{~m}$ \\
\hline & $1 \mathrm{~B}$ & $34.10 \pm 2.40 \mathrm{hi}$ & $5.12 \pm 0.04$ & $0.81 \pm 0.01$ & $27.58 \pm 2.03 \mathrm{ijk}$ & $145.49 \pm 1.701$ \\
\hline & $2 \mathrm{~A}$ & $23.70 \pm 3.061$ & $6.12 \pm 0.22$ & $0.80 \pm 0.05$ & $25.72 \pm 1.60 \mathrm{ijkl}$ & $163.56 \pm 2.74 \mathrm{k}$ \\
\hline & $2 \mathrm{~B}$ & $37.70 \pm 0.46 \mathrm{~h}$ & $5.92 \pm 0.58$ & $0.79 \pm 0.04$ & $35.42 \pm 0.93 \mathrm{~h}$ & $202.35 \pm 4.35 \mathrm{~h}$ \\
\hline \multirow[t]{6}{*}{15} & Control A & $25.85 \pm 0.14 \mathrm{kl}$ & $5.07 \pm 0.68$ & $0.87 \pm 0.03$ & $14.87 \pm 0.60 \mathrm{opq}$ & $79.40 \pm 1.59 n$ \\
\hline & Control B & $28.84 \pm 0.28 \mathrm{ijkl}$ & $5.58 \pm 0.39$ & $0.89 \pm 0.01$ & $15.53 \pm 0.41$ nopq & $76.20 \pm 2.44 n$ \\
\hline & $1 \mathrm{~A}$ & $47.76 \pm 2.36 \mathrm{~g}$ & $6.26 \pm 1.14$ & $0.82 \pm 0.03$ & $27.92 \pm 1.19 \mathrm{ij}$ & $168.22 \pm 3.37 \mathrm{ijk}$ \\
\hline & $1 \mathrm{~B}$ & $34.19 \pm 0.78 \mathrm{hi}$ & $5.85 \pm 0.56$ & $0.81 \pm 0.01$ & $29.90 \pm 0.97 \mathrm{i}$ & $177.55 \pm 1.94 \mathrm{i}$ \\
\hline & $2 \mathrm{~A}$ & $62.25 \pm 0.57 \mathrm{~cd}$ & $5.81 \pm 0.40$ & $0.76 \pm 0.03$ & $29.65 \pm 2.21 \mathrm{i}$ & $176.42 \pm 2.52 \mathrm{ij}$ \\
\hline & $2 \mathrm{~B}$ & $53.51 \pm 3.96$ ef & $6.47 \pm 0.22$ & $0.77 \pm 0.02$ & $37.91 \pm 2.97 \mathrm{fgh}$ & $243.61 \pm 3.80 \mathrm{~g}$ \\
\hline \multirow[t]{6}{*}{30} & Control A & $17.45 \pm 1.39 \mathrm{~m}$ & $5.05 \pm 0.86$ & $0.89 \pm 0.02$ & $22.39 \pm 0.81 \mathrm{klm}$ & $114.59 \pm 1.88 \mathrm{~m}$ \\
\hline & Control B & $26.34 \pm 1.14 \mathrm{kl}$ & $5.29 \pm 0.40$ & $0.88 \pm 0.02$ & $23.00 \pm 1.47 \mathrm{jklm}$ & $117.35 \pm 0.24 \mathrm{~m}$ \\
\hline & $1 \mathrm{~A}$ & $46.85 \pm 0.46 \mathrm{~g}$ & $5.91 \pm 0.15$ & $0.81 \pm 0.01$ & $36.73 \pm 2.35 \mathrm{gh}$ & $206.66 \pm 1.86 \mathrm{~h}$ \\
\hline & $1 \mathrm{~B}$ & $32.11 \pm 1.30$ hij & $5.78 \pm 0.34$ & $0.80 \pm 0.03$ & $38.22 \pm 1.36 \mathrm{fgh}$ & $210.03 \pm 3.49 \mathrm{~h}$ \\
\hline & $2 \mathrm{~A}$ & $62.16 \pm 1.93 \mathrm{~cd}$ & $6.26 \pm 0.32$ & $0.70 \pm 0.02$ & $38.02 \pm 2.69 \mathrm{fgh}$ & $237.42 \pm 2.09 \mathrm{~g}$ \\
\hline & $2 \mathrm{~B}$ & $36.85 \pm 0.63 \mathrm{~h}$ & $6.61 \pm 0.24$ & $0.71 \pm 0.02$ & $40.27 \pm 0.76$ efgh & $256.17 \pm 1.89 \mathrm{f}$ \\
\hline \multirow[t]{6}{*}{60} & Control A & $11.32 \pm 1.65$ no & $6.85 \pm 0.15$ & $0.87 \pm 0.07$ & $20.90 \pm 3.12 \mathrm{lmn}$ & $157.87 \pm 2.66 \mathrm{k}$ \\
\hline & Control B & $35.16 \pm 1.04 \mathrm{~h}$ & $6.90 \pm 0.18$ & $0.84 \pm 0.03$ & $24.70 \pm 0.71 \mathrm{ijklm}$ & $165.73 \pm 1.66 \mathrm{jk}$ \\
\hline & $1 \mathrm{~A}$ & $66.44 \pm 1.10 \mathrm{~cd}$ & $7.14 \pm 0.44$ & $0.77 \pm 0.01$ & $43.36 \pm 1.40 \mathrm{cdef}$ & $285.83 \pm 4.77 \mathrm{e}$ \\
\hline & $1 \mathrm{~B}$ & $60.56 \pm 0.34 \mathrm{de}$ & $7.49 \pm 0.06$ & $0.70 \pm 0.01$ & $42.46 \pm 1.91 \mathrm{def}$ & $283.67 \pm 2.31 \mathrm{e}$ \\
\hline & $2 \mathrm{~A}$ & $51.12 \pm 1.76 \mathrm{fg}$ & $7.20 \pm 0.15$ & $0.70 \pm 0.01$ & $41.50 \pm 0.85 \mathrm{defg}$ & $314.36 \pm 3.39 \mathrm{~d}$ \\
\hline & $2 \mathrm{~B}$ & $74.27 \pm 1.81 \mathrm{~b}$ & $6.86 \pm 0.23$ & $0.76 \pm 0.03$ & $49.66 \pm 1.01 \mathrm{~b}$ & $372.13 \pm 2.97 b$ \\
\hline \multirow[t]{6}{*}{90} & Control A & $29.43 \pm 1.00 \mathrm{ijkl}$ & $6.36 \pm 0.79$ & $0.82 \pm 0.02$ & $23.13 \pm 0.31 \mathrm{jklm}$ & $159.13 \pm 5.34 \mathrm{k}$ \\
\hline & Control B & $54.60 \pm 0.99 \mathrm{ef}$ & $6.90 \pm 0.11$ & $0.83 \pm 0.04$ & $29.17 \pm 1.11 \mathrm{i}$ & $200.12 \pm 4.55 \mathrm{~h}$ \\
\hline & $1 \mathrm{~A}$ & $45.72 \pm 2.10 \mathrm{~g}$ & $7.17 \pm 0.32$ & $0.74 \pm 0.04$ & $45.23 \pm 0.60$ bcde & $332.35 \pm 3.61 c$ \\
\hline & $1 \mathrm{~B}$ & $58.08 \pm 1.59 \mathrm{de}$ & $7.00 \pm 0.19$ & $0.79 \pm 0.05$ & $48.01 \pm 1.73 \mathrm{bc}$ & $342.25 \pm 4.40 \mathrm{c}$ \\
\hline & $2 \mathrm{~A}$ & $51.04 \pm 1.27 \mathrm{fg}$ & $7.57 \pm 0.32$ & $0.70 \pm 0.01$ & $46.21 \pm 1.20 \mathrm{bcd}$ & $362.72 \pm 4.90 \mathrm{~b}$ \\
\hline & $2 \mathrm{~B}$ & $80.69 \pm 0.02 \mathrm{a}$ & $7.41 \pm 0.11$ & $0.71 \pm 0.01$ & $57.97 \pm 0.04 \mathrm{a}$ & $425.86 \pm 1.38 \mathrm{a}$ \\
\hline
\end{tabular}


No significant differences in springiness or resilience were shown among the bread samples and during the storage times, whatever the type and level of salt (Table 6). Up to 30 days of storage, no remarkable differences were recorded among the breads (mean value of $5.7 \mathrm{~mm}$ ); after 60 days, the values of springiness increased by up to $7.0 \mathrm{~mm}$. These findings do not agree with those reported by [39].

As for resilience, the average value was around 0.80. During the entire storage period, the two controls showed higher resilience values. From the end of the baking to the end of storage, resilience values decreased slightly. These findings agree with those reported by [39].

With regard to gumminess and chewiness, they increased progressively with increasing storage times and with decreasing salt content, regardless of type, until they reach the maximum at 190 for $2 \mathrm{~B}$ (58.0 and 426.0). During the entire storage time, the two controls always showed the lowest values, and were similar to each other, except for 190 .

Water activity $\left(\mathrm{a}_{\mathrm{w}}\right)$ and moisture content were significant compared to all the factors of variability (Table 7). As for $\mathrm{pH}$ and HMF, they were significant compared to all the factors of variability $(p \leq 0.001$; Table 7).

Table 7. Analysis of variance of the chemical and color parameters studied on the loaves ( $p$-values).

\begin{tabular}{|c|c|c|c|c|c|c|c|c|c|c|c|}
\hline \multirow{2}{*}{ Factors of Variability } & \multirow{2}{*}{ Degrees of Freedom } & \multirow[t]{2}{*}{$a_{w}$} & \multirow[t]{2}{*}{ Moisture } & \multirow[t]{2}{*}{$\mathrm{pH}$} & \multirow[t]{2}{*}{ HMF } & \multicolumn{3}{|c|}{ Crumb } & \multicolumn{3}{|c|}{ Crust } \\
\hline & & & & & & $L^{*}$ & $a^{*}$ & $b^{*}$ & $L^{*}$ & $a^{*}$ & $b^{*}$ \\
\hline Type (A) & 5 & 0.000 & 0.000 & 0.000 & 0.000 & 0.005 & 0.000 & 0.000 & 0.000 & 0.000 & 0.000 \\
\hline Storage time (B) & 4 & 0.000 & 0.032 & 0.000 & 0.000 & 0.020 & 0.000 & 0.000 & 0.009 & 0.000 & 0.116 \\
\hline $\mathrm{A} \times \mathrm{B}$ & 20 & 0.000 & 0.000 & 0.000 & 0.000 & 0.011 & 0.033 & 0.069 & 0.002 & 0.007 & 0.133 \\
\hline
\end{tabular}

Crumb lightness and redness were significant compared to all the factors of variability. Crumb yellowness was significant for bread (A) and storage time (B) $(p \leq 0.001)$ but not for their interaction $(\mathrm{A} \times \mathrm{B})$ (Table 7). The effect of the addition of sea salt with reduced $\mathrm{Na}^{+}$on the $L^{*}$ parameter of crumb during the entire time storage was not significant (Table 7).

Chemical properties of the breads during the storage time are reported in Table 8.

Crumb $\mathrm{a}_{\mathrm{w}}$ is an important parameter of food processing and conservation technologies that comes into play for food stability and safety. It indicates the amount of free water not linked by bonds with the soluble constituents of the food, i.e., the water that can participate in chemical, physical, biological, and enzymatic reactions.

In general, water activity is a relatively easy parameter to measure, which can be an advantage, especially in the food industry [57].

The $\mathrm{a}_{\mathrm{w}}$ value ranged from about 0.88 for Control $\mathrm{A}$ at $\mathrm{t} 90$, to 0.93 for $2 \mathrm{~A}$ at $\mathrm{t} 0$ (Table 7). Similar values have been reported by [55].

After baking, and up to t15, there is no difference among the breads. From t30, water activity decreases for both controls. From t60 to the end of storage, $\mathrm{a}_{\mathrm{w}}$ decreases slightly for all the types. At t90, only the $a_{w}$ value of Control A is lower than the other types. Moisture content ranged from about $35.5-38.4 \%$ at the beginning (Table 8 ). Bread samples containing natural low $\mathrm{Na}^{+}$sea salt show the highest moisture content, and significant differences were found between all the breads. During storage, the breads with $\mathrm{NaCl}$ generally show the highest levels of moisture, and at 90 days of storage, the moisture content decreased, ranging from 35.3-32.4\%. No significant differences were found between control B and samples $1 \mathrm{~B}\left(1.22 \%\right.$ and $0.25 \%$ Saltwell $\left.{ }^{\circledR}\right)$ and the bread samples with the lowest levels of salt (2A and 2B).

The $\mathrm{pH}$ ranges from 5.36 to 5.93 at the beginning; at 90 days of storage, it ranges from 5.73 to 5.82 (Table 8). The variability seems to be more related to the storage time rather than to the different levels and salts used in the recipe. Similar trends were reported both for durum wheat bread with yeast extract and fortified with fiber $[28,50]$. 
Table 8. Evaluation of the chemical characteristics of the bread samples produced using different types and levels of sea salt during storage (data are means \pm standard deviations).

\begin{tabular}{|c|c|c|c|c|c|}
\hline Days of Storage & Type & $\mathbf{a}_{\mathrm{w}}$ & Moisture (\%) & $\mathrm{pH}$ & HMF (mg/kg Dry Matter) \\
\hline \multirow[t]{6}{*}{0} & Control A & $0.92 \pm 0.00 \mathrm{abc}$ & $35.5 \pm 0.07 \mathrm{n}$ & $5.65 \pm 0.01 \mathrm{i}$ & $28.9 \pm 1.73$ fghi \\
\hline & Control B & $0.92 \pm 0.00 \mathrm{a}$ & $37.1 \pm 0.02 \mathrm{~g}$ & $5.81 \pm 0.00 \mathrm{efg}$ & $32.6 \pm 2.18 \mathrm{de}$ \\
\hline & $1 \mathrm{~A}$ & $0.92 \pm 0.00 \mathrm{ab}$ & $36.1 \pm 0.051$ & $5.88 \pm 0.01 \mathrm{cde}$ & $34.3 \pm 1.40 \mathrm{~cd}$ \\
\hline & $1 \mathrm{~B}$ & $0.92 \pm 0.00 \mathrm{ab}$ & $38.4 \pm 0.04 \mathrm{~b}$ & $5.94 \pm 0.01 \mathrm{abc}$ & $38.2 \pm 1.19 \mathrm{~b}$ \\
\hline & $2 \mathrm{~A}$ & $0.93 \pm 0.00 \mathrm{a}$ & $35.8 \pm 0.07 \mathrm{~m}$ & $5.36 \pm 0.001$ & $39.2 \pm 2.81 \mathrm{~b}$ \\
\hline & $2 \mathrm{~B}$ & $0.92 \pm 0.00 \mathrm{a}$ & $36.7 \pm 0.07 \mathrm{~h}$ & $5.93 \pm 0.02 \mathrm{abc}$ & $23.0 \pm 1.07$ mnopqr \\
\hline \multirow[t]{6}{*}{15} & Control A & $0.91 \pm 0.00 \mathrm{bcdef}$ & $36.6 \pm 0.02 \mathrm{hi}$ & $5.80 \pm 0.00 \mathrm{~g}$ & $37.6 \pm 0.58 \mathrm{bc}$ \\
\hline & Control B & $0.92 \pm 0.00$ abcde & $35.7 \pm 0.08 \mathrm{mn}$ & $5.88 \pm 0.01 \mathrm{cdef}$ & $29.2 \pm 0.51 \mathrm{efgh}$ \\
\hline & $1 \mathrm{~A}$ & $0.92 \pm 0.00 \mathrm{abcd}$ & $39.5 \pm 0.04 \mathrm{a}$ & $5.92 \pm 0.01 \mathrm{abc}$ & $30.3 \pm 0.98 \mathrm{efg}$ \\
\hline & $1 \mathrm{~B}$ & $0.92 \pm 0.00 \mathrm{abcd}$ & $37.9 \pm 0.06 \mathrm{~cd}$ & $5.93 \pm 0.02 a b c$ & $30.8 \pm 1.61 \mathrm{def}$ \\
\hline & $2 \mathrm{~A}$ & $0.92 \pm 0.00 \mathrm{abcd}$ & $37.12 \pm 0.04 \mathrm{~g}$ & $5.92 \pm 0.01 \mathrm{abc}$ & $29.2 \pm 0.64$ efgh \\
\hline & $2 \mathrm{~B}$ & $0.92 \pm 0.01 \mathrm{abcd}$ & $36.7 \pm 0.08 \mathrm{~h}$ & $5.96 \pm 0.01 \mathrm{ab}$ & $27.9 \pm 1.37$ fghij \\
\hline \multirow[t]{6}{*}{30} & Control A & $0.91 \pm 0.00$ defgh & $35.9 \pm 0.04 \mathrm{~lm}$ & $5.73 \pm 0.01 \mathrm{~h}$ & $24.9 \pm 0.27$ jklmnop \\
\hline & Control B & $0.91 \pm 0.01$ cdefg & $35.8 \pm 0.02 \mathrm{~m}$ & $5.78 \pm 0.00 \mathrm{gh}$ & $21.0 \pm 0.14 \mathrm{gr}$ \\
\hline & $1 \mathrm{~A}$ & $0.92 \pm 0.00 \mathrm{abcd}$ & $37.7 \pm 0.05 \mathrm{de}$ & $5.99 \pm 0.04 \mathrm{a}$ & $21.5 \pm 0.03 \mathrm{pqr}$ \\
\hline & $1 \mathrm{~B}$ & $0.92 \pm 0.00$ abcde & $36.4 \pm 0.07 \mathrm{i}$ & $5.88 \pm 0.02 \mathrm{cdef}$ & $24.1 \pm 1.14$ lmnopqr \\
\hline & $2 \mathrm{~A}$ & $0.92 \pm 0.00 \mathrm{abcd}$ & $37.3 \pm 0.04 \mathrm{fg}$ & $5.84 \pm 0.02 \mathrm{defg}$ & $37.8 \pm 0.09 \mathrm{bc}$ \\
\hline & $2 \mathrm{~B}$ & $0.92 \pm 0.00 \mathrm{abcd}$ & $35.9 \pm 0.03 \mathrm{~lm}$ & $5.93 \pm 0.02 a b c$ & $16.3 \pm 0.03 \mathrm{~s}$ \\
\hline \multirow[t]{6}{*}{60} & Control A & $0.90 \pm 0.00 j$ & $37.3 \pm 0.07 \mathrm{fg}$ & $5.82 \pm 0.03 \mathrm{efg}$ & $45.8 \pm 0.07 \mathrm{a}$ \\
\hline & Control B & $0.90 \pm 0.00 \mathrm{ghij}$ & $35.0 \pm 0.02 \mathrm{p}$ & $5.81 \pm 0.01 \mathrm{fg}$ & $22.4 \pm 0.20$ nopqr \\
\hline & $1 \mathrm{~A}$ & $0.91 \pm 0.00$ efghij & $37.5 \pm 0.16 \mathrm{ef}$ & $5.83 \pm 0.01 \mathrm{efg}$ & $27.7 \pm 0.05$ fghijk \\
\hline & 1B & $0.91 \pm 0.00$ efghij & $38.1 \pm 0.06 c$ & $5.78 \pm 0.01 \mathrm{gh}$ & $26.0 \pm 0.15 \mathrm{hijklm}$ \\
\hline & $2 \mathrm{~A}$ & $0.91 \pm 0.00$ defghi & $36.1 \pm 0.021$ & $5.83 \pm 0.00 \mathrm{efg}$ & $25.0 \pm 0.03$ jklmno \\
\hline & $2 \mathrm{~B}$ & $0.91 \pm 0.00$ defgh & $38.1 \pm 0.08 \mathrm{c}$ & $5.91 \pm 0.01 \mathrm{bcd}$ & $26.8 \pm 0.08$ ghijkl \\
\hline \multirow[t]{6}{*}{90} & Control A & $0.88 \pm 0.01 \mathrm{k}$ & $34.8 \pm 0.06 p$ & $5.73 \pm 0.04 \mathrm{~h}$ & $25.5 \pm 0.13$ ijklmn \\
\hline & Control B & $0.90 \pm 0.00 \mathrm{ij}$ & $34.2 \pm 0.02 \mathrm{q}$ & $5.81 \pm 0.01 \mathrm{fg}$ & $24.2 \pm 0.30 \mathrm{klmnopq}$ \\
\hline & $1 \mathrm{~A}$ & $0.90 \pm 0.00 \mathrm{hij}$ & $35.3 \pm 0.07 \mathrm{o}$ & $5.78 \pm 0.00 \mathrm{gh}$ & $20.6 \pm 0.13 \mathrm{r}$ \\
\hline & $1 \mathrm{~B}$ & $0.90 \pm 0.00 \mathrm{fghij}$ & $34.2 \pm 0.01 \mathrm{q}$ & $5.82 \pm 0.08 \mathrm{efg}$ & $22.6 \pm 0.03$ mnopqr \\
\hline & $2 \mathrm{~A}$ & $0.90 \pm 0.00$ fghij & $32.4 \pm 0.04 \mathrm{r}$ & $5.80 \pm 0.01 \mathrm{gh}$ & $21.5 \pm 0.27$ opqr \\
\hline & $2 \mathrm{~B}$ & $0.90 \pm 0.00 \mathrm{fghij}$ & $32.4 \pm 0.01 \mathrm{r}$ & $5.82 \pm 0.00 \mathrm{efg}$ & $21.8 \pm 0.00 \mathrm{opqr}$ \\
\hline
\end{tabular}

Different letters in the same column indicate significant difference $(p \leq 0.01)$.

HMF is a widely used compound as heat induces the chemical index generally used for monitoring thermal abuse [58-61]. In bread and in other baking products, HMF is used to monitor the heating process, and several factors influence its formation, such as manufacturing conditions and recipe [57-59]. Even if the toxicity risk of HMF is still debated, nowadays, HMF is under evaluation as an emerging ubiquitous processing contaminant since there is evidence to suggest that HMF and its metabolites may have harmful effects on human health [60-63].

Among foods, coffee and bread contribute the most HMF exposure, about $85 \%$ of total intake [64].

The HMF parameter was significant compared to all the factors of variability $(p \leq 0.001$; Table 7$)$. HMF levels at the beginning ranged from about 23 to $39 \mathrm{mg} / \mathrm{kg}$ of dry matter (Table 8), and significant differences were found between all samples. These levels were lower than those reported for durum wheat bread with $\mathrm{KCl}$ and taste enhancer [28], and it is known that differences in water content in the leavening and/or baking time and the ratio between crumb and crust of the loaf could influence HMF content [58]. Bread samples with the lowest levels of natural low $\mathrm{Na}^{+}$sea salt $(2 \mathrm{~B})$ had the lowest HMF content. During storage, a decrease in HMF amount was highlighted, though the trend in decrease was not regular. Generally, the bread samples with the lowest levels of salt had the lowest HMF content due to the effects of a high level of $\mathrm{NaCl}$ on starch degradation and yeast growth, resulting, in both cases, in higher levels of Maillard indicators [65]. At 90 days of storage, this parameter ranged from about 20.6 to $25.5 \mathrm{mg} / \mathrm{kg}$ of dry matter. The HMF trend during storage was similar to those reported by $[28,50]$, suggesting that HMF decrease is more related to storage time rather than recipe.

During storage, crumb redness in the traditional sea salt (control A) test slowly decreased. After t15, the $a^{*}$ value begins to decrease for all breads (Table S1). 


\subsection{Sensory Evaluation}

The addition of different types and quantities of sea salt had little effect on the sensory characteristics of the bread sample. Table 9 reports the ANOVA results of sensory data and the bread attributes, which significantly differentiated at different $p$-levels $(p \leq 0.05 ; p \leq 0.01 ; p \leq 0.001)$, at each sampling. Mean values were reported only for significantly different attributes.

Table 9. Influence of type of bread (6) on the attributes and mean scores of the significant sensory attributes (comparison of formulations). Data expressed as means.

\begin{tabular}{|c|c|c|c|c|c|c|c|c|}
\hline \multirow{2}{*}{ Days of Storage } & \multirow{2}{*}{ Attributes } & \multirow{2}{*}{ F Values } & \multicolumn{6}{|c|}{ Type } \\
\hline & & & Control A & Control B & $1 \mathrm{~A}$ & 1B & $2 \mathrm{~A}$ & 2B \\
\hline 0 & Salty & $12.08^{* * *}$ & $4.2 \mathrm{~b}$ & $4.3 \mathrm{~b}$ & $1.6 \mathrm{a}$ & $1.6 \mathrm{a}$ & $1.6 \mathrm{a}$ & $1.5 \mathrm{a}$ \\
\hline \multirow[t]{4}{*}{15} & Sweet & $5.23 * * *$ & $2.9 \mathrm{a}$ & $3.0 \mathrm{a}$ & $4.3 \mathrm{ab}$ & $5.2 \mathrm{bc}$ & $5.8 \mathrm{c}$ & $5.0 \mathrm{bc}$ \\
\hline & Salty & $7.49 * * *$ & $4.4 \mathrm{~b}$ & $4.1 \mathrm{~b}$ & $1.9 \mathrm{a}$ & $1.9 \mathrm{a}$ & $1.4 \mathrm{a}$ & $1.7 \mathrm{a}$ \\
\hline & Bread flavor & $2.98 *$ & $6.1 \mathrm{~b}$ & $6.2 \mathrm{~b}$ & $4.9 \mathrm{ab}$ & $4.1 \mathrm{a}$ & $4.6 \mathrm{ab}$ & $3.6 \mathrm{a}$ \\
\hline & Overall evaluation & $5.01 * * *$ & $6.5 \mathrm{~b}$ & $6.3 \mathrm{~b}$ & $4.1 \mathrm{a}$ & $3.9 \mathrm{a}$ & $4.2 \mathrm{a}$ & $3.4 \mathrm{a}$ \\
\hline \multirow[t]{4}{*}{30} & Sweet & $5.30 * * *$ & $3.1 \mathrm{ab}$ & $2.8 \mathrm{a}$ & $4.3 \mathrm{abc}$ & $4.6 \mathrm{bc}$ & $6.4 \mathrm{~d}$ & $5.3 \mathrm{~cd}$ \\
\hline & Salty & $7.40 * * *$ & $3.9 \mathrm{~b}$ & $4.2 \mathrm{~b}$ & $2.4 \mathrm{a}$ & $2.2 \mathrm{a}$ & $1.6 \mathrm{a}$ & $1.7 \mathrm{a}$ \\
\hline & Bread flavor & $2.45 * *$ & $5.4 \mathrm{~b}$ & $5.5 \mathrm{~b}$ & $4.6 \mathrm{ab}$ & $3.8 \mathrm{ab}$ & $3.3 \mathrm{a}$ & $3.5 \mathrm{a}$ \\
\hline & Overall evaluation & $3.48^{* *}$ & $5.8 \mathrm{~b}$ & $5.7 \mathrm{~b}$ & $4.6 \mathrm{ab}$ & $3.8 \mathrm{a}$ & $3.3 \mathrm{a}$ & $3.6 \mathrm{a}$ \\
\hline \multirow[t]{3}{*}{60} & Sweet & $3.25 *$ & $2.9 \mathrm{a}$ & $3.4 \mathrm{a}$ & $4.1 \mathrm{ab}$ & $4.4 \mathrm{ab}$ & $5.6 \mathrm{~b}$ & $5.0 \mathrm{~b}$ \\
\hline & Salty & $9.45 * * *$ & $5.2 \mathrm{~b}$ & $4.8 \mathrm{~b}$ & $2.8 \mathrm{~b}$ & $3.2 \mathrm{~b}$ & $1.9 \mathrm{ab}$ & $1.3 \mathrm{a}$ \\
\hline & Overall & $3.17 *$ & $5.4 \mathrm{bc}$ & $5.6 \mathrm{c}$ & $4.0 \mathrm{ab}$ & $4.3 \mathrm{abc}$ & $3.7 \mathrm{a}$ & $3.2 \mathrm{a}$ \\
\hline \multirow[t]{3}{*}{90} & Sweet & $6.45^{* * *}$ & $5.4 \mathrm{bc}$ & $5.6 \mathrm{c}$ & $3.8 \mathrm{ab}$ & $4.1 \mathrm{abc}$ & $3.5 \mathrm{a}$ & $3.3 \mathrm{a}$ \\
\hline & Salty & $12.45^{* * *}$ & $5.0 \mathrm{~b}$ & $4.5 \mathrm{~b}$ & $2.3 \mathrm{a}$ & $2.4 \mathrm{a}$ & $1.8 \mathrm{a}$ & $2.4 \mathrm{a}$ \\
\hline & Overall evaluation & $2.87 *$ & $5.4 \mathrm{bc}$ & $5.6 \mathrm{c}$ & $3.8 \mathrm{ab}$ & $4.1 \mathrm{abc}$ & $3.5 \mathrm{a}$ & $3.3 \mathrm{a}$ \\
\hline
\end{tabular}

Different letters in the same row indicate significant differences at $p \leq 0.05^{*}, p \leq 0.01^{* *}, p \leq 0.001^{* * *}$.

At $t 0$, the bread samples were evaluated similarly by panellists, with the exception of the "salty" attribute. Obviously, the control breads (Control A and Control B) had the highest value of saltiness.

At 15 and 30 days of storage, the samples were significantly different for the attributes sweet, salty, bread flavor, and overall evaluation. The $0.15 \mathrm{NaCl}$ sample showed the highest intensity of sweet taste, while the control samples, as expected, had the highest score of salt, bread flavor, and overall evaluation.

At 60 and 90 days of storage, the attributes of sweet, salty, and overall significantly differentiated the bread samples. The $0.15 \mathrm{NaCl}$ and 0.15 Saltwell $^{\circledR}$ bread samples had the highest intensity of sweet and the lowest of the attributes salt and overall. The control samples showed the highest intensity of the attribute overall.

The different levels of sea salt did not influence the attributes of texture (i.e., softness), as reported by [28].

Table 10 reports the sensory attributes which significantly differentiated $(p \leq 0.05)$ during the 90 days of storage. 
Table 10. Mean values of the significantly different sensory attributes (comparison during storage). Three bread loaves were collected at each sampling.

\begin{tabular}{|c|c|c|c|c|c|c|c|}
\hline Attribute & Days of Storage & Control A & Control B & $1 \mathrm{~A}$ & 1B & $2 \mathrm{~A}$ & 2B \\
\hline \multirow{5}{*}{ Elasticity } & 0 & & $6.1 \mathrm{ab}$ & & & & \\
\hline & 15 & & $7.5 \mathrm{~b}$ & & & & \\
\hline & 30 & & $6.5 \mathrm{ab}$ & & & & \\
\hline & 60 & & $5.0 \mathrm{a}$ & & & & \\
\hline & 90 & & $5.5 \mathrm{a}$ & & & & \\
\hline \multirow{5}{*}{ Humidity } & 0 & $7.2 \mathrm{~b}$ & $6.5 \mathrm{~b}$ & & & $7.2 \mathrm{~b}$ & \\
\hline & 15 & $6.7 \mathrm{~b}$ & $6.1 \mathrm{~b}$ & & & $5.7 \mathrm{ab}$ & \\
\hline & 30 & $4.3 \mathrm{a}$ & $5.6 \mathrm{~b}$ & & & $5.1 \mathrm{a}$ & \\
\hline & 60 & $4.4 \mathrm{a}$ & $3.8 \mathrm{a}$ & & & $4.0 \mathrm{a}$ & \\
\hline & 90 & $4.8 \mathrm{a}$ & $5.2 \mathrm{ab}$ & & & $4.4 \mathrm{a}$ & \\
\hline \multirow{5}{*}{ Softness } & 0 & $6.5 \mathrm{bc}$ & $6.3 \mathrm{~b}$ & & & & \\
\hline & 15 & $6.8 c$ & $6.8 \mathrm{~b}$ & & & & \\
\hline & 30 & $5.2 \mathrm{abc}$ & $5.4 \mathrm{ab}$ & & & & \\
\hline & 60 & $4.4 \mathrm{a}$ & $4.2 \mathrm{a}$ & & & & \\
\hline & 90 & $4.9 \mathrm{ab}$ & $5.4 \mathrm{ab}$ & & & & \\
\hline
\end{tabular}

Different letters in the same column indicate significant difference at $p \leq 0.05$.

Control A showed a significant decrease during storage but only for the attributes of humidity and softness. At 0 and 15 days of storage, Control A had the highest intensity of these two sensory attributes.

Control B showed a significant decrease during storage for the attributes of elasticity, humidity, and softness. These attributes began to decrease after 30 days of storage.

Sample 2A showed a significant decrease only for the attribute humidity, while bread samples $1 \mathrm{~A}$, $1 \mathrm{~B}$, and $2 \mathrm{~B}$ did not show any significant differences during the 90 days of storage.

During storage, the bread samples did not develop off-odors or off-flavors in agreement with those reported by [28].

\subsection{Multivariate Statistical Analysis}

Principal component analysis (PCA) is a multivariate analysis that allows the reduction and interpretation of large multivariate datasets with some underlying linear structure. In this trial, it was carried out to determine if and which salt (type and concentration) had an influence on the qualitative and sensory traits of the breads. The PCA included the following 24 dependent variables: specific volume, specific weight, $\mathrm{h} / \mathrm{d}$ ratio, crumb porosity, hardness, gumminess, chewiness, springiness, resilience, water activity, moisture, $\mathrm{pH}, \mathrm{HMF}$, acidity, and crust and crumb color parameters (as $L^{*}, a^{*}, b^{*}, h, C$ ).

The two main factors accounting for $56.92 \%$ of the total variance were PC1 and PC2 at $37.08 \%$ and $19.84 \%$ (Figure 1).

There are two types of trends on the first axis: (1) based on salt content, the groups shift from the negative to the positive section, from the breads with minimum salt concentrations (2A and $2 \mathrm{~B}$ ), to those with more (Control A and Control B) (Figure 1); (2) based on days of storage, from the longest ( $\mathrm{t} 90$ ) to the shortest ( $\mathrm{t} 0$ ) (Figure 1). Convex hulls were used to highlight these trends. They can be defined as the intersection of all convex sets containing a given subset of a Euclidean space. The convex hull of a set of data is the smallest convex set that contains it. 


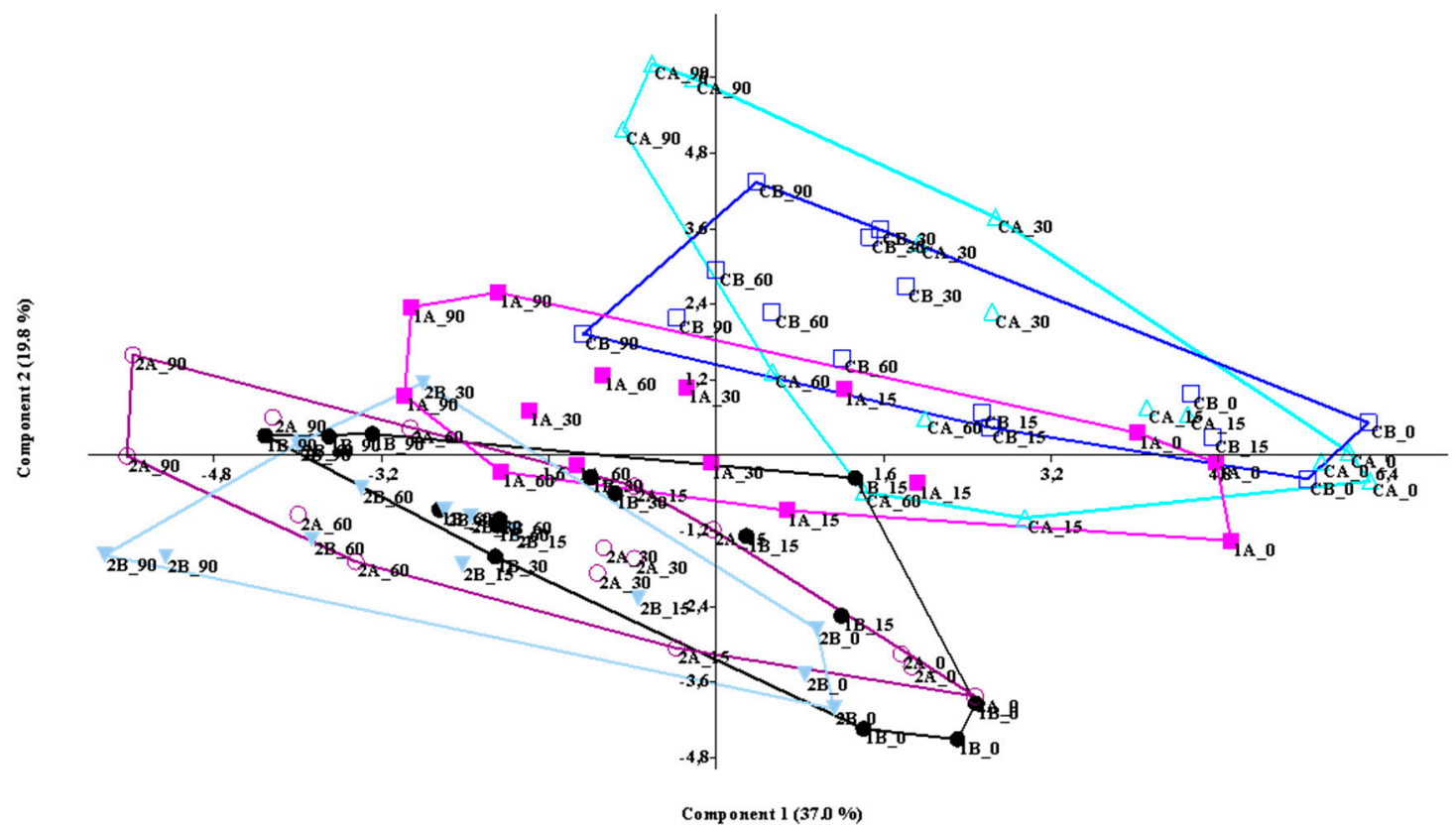

Figure 1. Principal component analysis (PCA) scatter diagram defined by the first two principal components (i.e., PC1, PC2) and convex hulls for the measured physico-chemical and textural traits of the breads, grouped by storage time.

The variables that determined these trends were resilience, crust color (as $\left.a^{*}, C\right), \mathrm{h} / \mathrm{d}$ ratio, crumb color $(h)$, and moisture, which showed the highest positive loading values $(0.272,0.230,0.227,0.228$, 0.218 , and 0.209 respectively), chewiness, hardness, gumminess, and springiness, with the highest negative loadings $(-0.314,-0.311,-0.309,-0.263$, respectively).

The groups also showed a gradient with respect to the days of storage, if PC2 is observed: from the positive scores of the longer storage time to the gradually lower scores of the shorter ones (Figure 1).

The variables that positively correlated with PC2 were crust color parameters $\left(L^{*}, h, b^{*}\right)$ and moisture (loading values, 0.367, 0.334, 0.271, 0.292, respectively). Moreover, PC2 negatively correlated with $\mathrm{a}_{\mathrm{w}}$, specific volume, and crust hardness $(-0.294,-0.266,-0.248$, respectively).

In summary, sorting the data according to the first two axes distributes the groups in relation to the lowest salt concentration with the maximum storage time, and so on, up to the breads with the highest salt concentrations with the shortest storage times.

PCA loadings did not have the necessary strength to affect the net separation of groups, but this seems to support the hypothesis that the different breads and salt concentrations do not lead to substantial differences in the overall qualitative characteristics and acceptability of the product.

\section{Conclusions}

The results of this study showed that replacing traditional sea salt with Saltwell ${ }^{\circledR}$ in durum wheat bread is a possible strategy for reducing sodium intake while maintaining the quality and sensorial characteristics of the bread.

There were no significant differences in the specific volume and bread yield among bread samples and during storage times, regardless of the type and level of sea salt used. The textural data showed high hardness and chewiness values, with significant differences between samples and storage times.

Sensory data showed that the different levels of sea salt did not influence the attributes of softness.

Principal component analysis (PCA) seems to support these findings since, overall, the parameters analyzed were unable to differentiate groups effectively. 
Natural low sodium sea salt has made it possible to obtain durum wheat bread with the nutritional claim "low in sodium" $(<0.12 \mathrm{~g} / 100 \mathrm{~g})$ and/or "very low in sodium" $(<0.04 \mathrm{~g} / 100 \mathrm{~g})$ on food labels, in accordance with EU regulations [20-22]. However, the breads showed good taste and flavor.

These results should encourage the opportunity to produce low-sodium or very low-sodium bread because of consumers' increasing interest in durum wheat bread in accordance with the guidelines for a healthy diet.

Supplementary Materials: The following are available online at http://www.mdpi.com/2304-8158/9/6/752/s1, Table S1: Colour parameters of the bread samples produced using different types and levels of sea salt during storage (data are means \pm standard deviations). Three bread loaves were collected at each sampling..

Author Contributions: Conceptualization, E.A., S.M., V.G., and A.S.; data curation, S.M., A.M., and M.A.; formal analysis, S.M., A.M., V.G., and S.B.; funding acquisition, P.R. and B.F.; investigation, E.A. and A.S.; methodology, E.A., S.M., A.M., V.G., S.B., and A.S.; project administration, P.R. and B.F.; resources, E.A., P.R., B.F., and A.S.; software, S.M. and M.A.; supervision, E.A., P.R., B.F., and A.S.; validation, E.A., S.M., A.M., V.G., S.B., M.A., and A.S.; visualization, A.S.; writing—original draft, E.A., S.M., A.M., V.G., and A.S.; writing一review and editing, E.A., M.A. and A.S. All authors have read and agreed to the published version of the manuscript.

Funding: Part of this research was funded by the Regional Operational Program of "Regione Siciliana" PO FESR 2007-2013-Asse IV, Obiettivo 4.1.1-Linea di Intervento 4.1.1.2 with the title of the research program "Impiego e valutazione di fibre e sostanze nutraceutiche per l'ottenimento di prodotti da forno salutistici", grant number $5787 / 3$ of the $14 / 12 / 2011$.

Acknowledgments: The authors wish to thank Nick Field for scientific English language editorial assistance. The authors thank Medsalt-Mediterranean Salt Company S.r.l. (Rome, Italy) for kindly donating a sample of Saltwell ${ }^{\mathbb{R}}$.

Conflicts of Interest: The authors declare no conflict of interest. The funders had no role in the design of the study; in the collection, analyses, or interpretation of data; in the writing of the manuscript, or in the decision to publish the results.

\section{References}

1. Whelton, P.K.; He, J.; Gail, T.L. Lifestyle Modifications for the Prevention and Treatment of Hypertension; Whelton, P.K., He, J., Gail, T.L., Eds.; Marcel Dekker, Inc. Publisher's Location: New York, NY, USA, 2003; p. 403.

2. Appel, L.J; Frohlich, E.D.; Hall, J.E.; Pearson, T.A.; Sacco, R.L.; Seals, D.R.; Sacks, F.M.; Smith, S.C.; Vafiadis, D.K.; Van Horn, L.V. The importance of population-wide sodium reduction as a means to prevent cardiovascular disease and stroke: A call to action from the American Heart Association. Circulation 2011, 123, 1138-1143. [CrossRef]

3. Strazzullo, P.; D’Elia, L.; Kandala, N.B.; Cappuccio, F.P. Salt intake, stroke and cardiovascular disease: Meta-analysis of prospective studies. Br. Med. J. 2009, 339, b4567. [CrossRef] [PubMed]

4. Beaglehole, R.; Bonita, R.; Horton, R.; Adams, C.; Alleyne, G.; Asaria, P.; Baugh, V.; Bekedam, H.; Billo, N.; Casswell, S.; et al. Priority actions for the non-communicable disease crisis. Lancet 2011, 377, 1438-1447. [CrossRef]

5. Beauchamp, G.K.; Mennella, J.A. Early flavour learning and its impact on later feeding behaviour. J. Pediatr. Gastroenterol. Nutr. 2009, 48, S25-S30. [CrossRef] [PubMed]

6. Stein, L.J.; Cowart, B.J.; Beauchamp, G.K. The development of salty taste acceptance is related to dietary experience in human infants: A prospective study. Am. J. Clin. Nutr. 2012, 94, 123-129. [CrossRef] [PubMed]

7. Strazzullo, P.; Campanozzi, A.; Avallone, S. Does salt intake in the first two years of life affect the development of cardiovascular disorders in adult hood? Nutr. Metab. Cardiovasc. Dis. 2012, 22, 787-792. [CrossRef] [PubMed]

8. Strazzullo, P.; Cairella, G.; Campanozzi, A.; Carcea, M.; Galeone, D.; Galletti, F.; Giampaoli, S.; Iacoviello, L.; Scalfi, L. Population based strategy for dietary salt intake reduction: Italian initiatives in the European framework. Nutr. Metab. Cardiovasc. Dis. 2012, 22, 161-166. [CrossRef] [PubMed]

9. Donfrancesco, C.; Ippolito, R.; Lo Noce, C.; Palmieri, L.; Iacone, R.; Russo, O.; Vanuzzo, D.; Galletti, F.; Galeone, D.; Giampaoli, S.; et al. Excess dietary sodium and inadequate potassium intake in Italy: Results of the MINISAL study. Nutr. Metab. Cardiovasc. Dis. 2013, 23, 850-856. [CrossRef] 
10. Campanozzi, A.; Avallone, S.; Barbato, A.; Iacone, R.; Russo, O.; De Filippo, G.; D'Angelo, G.; Pensabene, L.; Malamisura, B.; Cecere, G.; et al. High Sodium and Low Potassium Intake among Italian Children: Relationship with Age, Body Mass and Blood Pressure. PLoS ONE 2015, 10, e0121183. [CrossRef]

11. Eaton, S.B.; Konner, M. Paleolithic nutrition. A consideration of its nature and current implications. N. Engl. J. Med. 1985, 312, 283-289. [CrossRef]

12. Leclercq, C.; Ferro-Luzzi, A. Total and domestic consumption of salt and their determinants in three regions of Italy. Eur. J. Clin. Nutr. 1991, 45, 151-159. [PubMed]

13. European Food Safety Authority (EFSA). Opinion of the scientific panel on dietetic products, nutrition and allergies on a request from the commission related to the tolerable upper intake level of sodium. EFSA J. 2005, 209, 1-26.

14. WASH World Action on Salt \& Health. Available online: http://www.worldactiononsalt.com/ (accessed on 3 May 2020).

15. CASH Consensus Action on Salt and Health. Available online: http://www.actiononsalt.org.uk/about (accessed on 3 May 2020).

16. Food Standard Agency. Food. Using Traffic Lights to Make Healthier Choices; Ancient House Printing Group: Ipswich, UK. Available online: http://www.resourcesorg.co.uk/assets/pdfs/foodtrafficlight1107.pdf (accessed on 3 May 2020).

17. Wyness, L.A.; Butriss, J.L.; Stanner, S.A. Reducing the population's sodium intake: The UK Food Standards Agency's salt reduction programme. Public Health Nutr. 2012, 15, 254-261. [CrossRef] [PubMed]

18. WHO \& FAO - World Health Organisation \& Food and Agriculture Organisation. Diet, Nutrition and the Prevention of Chronic Diseases; WHO Technical Report: Geneva, Switzerland, 2003; Volume 916, p. 149.

19. WHO World Health Organisation. Reducing Salt Intake in Populations. Report of a WHO Forum and Technical Meeting 5-7 October 2006, Paris, France. Geneva, Switzerland. 2007. Available online: http://www.who.int/dietphysicalactivity/Salt_Report_VC_april07.pdf (accessed on 3 May 2020).

20. European Parliament \& Council of the European Union. Regulation (EC) No. 1924/2006 of the European Parliament and of the Council of 20 December 2006 on nutrition and health claims made on foods. Off. J. Eur. Union (OJEU) 2006, L404, 9-25.

21. Commission Regulation (EU) No. 1047/2012 of 8 November 2012 amending Regulation (EC) No 1924/2006 with regard to the list of nutrition claims (Text with EEA relevance). Off. J. Eur. Union (OJEU) 2012, L310, 36-37.

22. European Parliament \& Council of the European Union. Regulation (EU) No. 1169/2011 of the European Parliament and of the Council of 25 October 2011 on the provision of food information to consumers. Off. J. Eur. Union (OJEU) 2011, L304, 18-63.

23. Lynch, E.J.; Dal Bello, F.; Sheehan, E.M.; Cashman, K.D.; Arendt, E.K. Fundamental studies on the reduction of salt on dough and bread characteristics. Food Res. Int. 2009, 42, 885-891. [CrossRef]

24. Pasqualone, A.; Caponio, F.; Pagani, M.A.; Summo, C.; Paradiso, V.M. Effect of salt reduction on quality and acceptability of durum wheat bread. Food Chem. 2019, 289, 575-581. [CrossRef]

25. Noort, J.H.F.; Bult, M.; Stieger, M. Saltiness enhancement by taste contrast in bread prepared with encapsulated salt. J. Cereal Sci. 2012, 55, 218-225. [CrossRef]

26. Simsek, S.; Martinez, M.O. Quality of dough and bread prepared with sea salt or sodium chloride. J. Food Process Eng. 2016, 39, 44-52. [CrossRef]

27. Miller, R.A.; Jeong, J. Sodium reduction in bread using low-sodium sea salt. Cereal Chem. 2014, 91, 41-44. [CrossRef]

28. Spina, A.; Brighina, S.; Muccilli, S.; Mazzaglia, A.; Rapisarda, P.; Fallico, B.; Arena, E. Partial Replacement of $\mathrm{NaCl}$ in Bread from Durum Wheat (Triticum turgidum L. subsp. durum Desf.) with $\mathrm{KCl}$ and Yeast Extract: Evaluation of Quality Parameters During Long Storage. Food Bioprocess Technol. 2015, 8, 1089-1101. [CrossRef]

29. Raffo, A.; Carcea, M.; Moneta, E.; Narducci, V.; Nicoli, S.; Peparaio, M.; Sinesio, F.; Turfani, V. Influence of different levels of sodium chloride and of a reduced-sodium salt substitute on volatiles formation and sensory quality of wheat bread. J. Cereal Sci. 2018, 79, 518-526. [CrossRef]

30. Sinesio, F.; Raffo, A.; Peparaio, M.; Moneta, E.; Civitelli, E.S.; Narducci, V.; Turfani, V.; Ferrari Nicoli, S.; Carcea, M. Impact of sodium reduction strategies on volatile compounds; sensory properties and consumer perception in commercial wheat bread. Food Chem. 2019, 301, 125252. [CrossRef] [PubMed] 
31. Delcour, J.; Hoseney, R.C. Principles of Cereal Science and Technology; AACC International: St. Paul, MN, USA, 2010.

32. Carcea, M.; Narducci, V.; Turfani, V.; Aguzzi, A. A survey of sodium chloride content in Italian artisanal and industrial bread. Foods 2018, 7, 181. [CrossRef] [PubMed]

33. Fiore, M.C.; Mercati, F.; Spina, A.; Blangiforti, S.; Venora, G.; Dell'Acqua, M.; Lupini, A.; Preiti, G.; Monti, M.; Pè, M.E.; et al. High-throughput genotyping, morphological and quality traits to assess genetic diversity of wheat landraces from Sicily. Plants 2019, 8, 116. [CrossRef] [PubMed]

34. Pasqualone, A. Italian Durum Wheat Breads. In Bread Consumption and Health; Pedrosa Silva Clerici, M.T., Ed.; Nova Science Publisher Inc.: Hauppauge, NY, USA, 2012; pp. 57-79.

35. Boyacioglu, M.H.; D'Appolonia, B.L. Characterization and utilization of durum wheat for breadmaking. I. Comparison of chemical, rheological, and baking properties between bread wheat flour and durum wheat flours. Cereal Chem. 1994, 71, 21-28.

36. Boyacioglu, M.H.; D'Appolonia, B.L. Characterization and utilization of durum wheat for breadmaking. II. Study of flour blends and various additives. Cereal Chem. 1994, 71, 28-34.

37. Liu, C.Y.; Shepherd, K.W.; Rathjen, A.J. Improvement of durum wheat pastamaking and breadmaking qualities. Cereal Chem. 1996, 73, 155-166.

38. Pasqualone, A.; De Angelis, D.; Squeo, G.; Difonzo, G.; Caponio, F.; Summo, C. The Effect of the Addition of Apulian black Chickpea Flour on the Nutritional and Qualitative Properties of Durum Wheat-Based Bakery Products. Foods 2019, 8, 504. [CrossRef]

39. Giannone, V.; Giarnetti, M.; Spina, A.; Todaro, A.; Pecorino, B.; Summo, C.; Caponio, F.; Paradiso, V.M.; Pasqualone, A. Physico-chemical properties and sensory profile of durum wheat Dittaino PDO (Protected Designation of Origin) bread and quality of re-milled semolina used for its production. Food Chem. 2018, 241, 242-249. [CrossRef] [PubMed]

40. Pasqualone, A.; Piergiovanni, A.R.; Caponio, F.; Paradiso, V.M.; Summo, C.; Simeone, R. Evaluation of the technological characteristics and bread-making quality of alternative wheat cereals in comparison with common and durum wheat. Food Sci. Technol. Int. 2011, 17, 135-142. [CrossRef] [PubMed]

41. Palumbo, M.; Spina, A.; Boggini, G. Bread-making quality of Italian durum wheat (Triticum durum Desf.) cultivars. Ital. J. Food Sci. 2002, 14, 123-134.

42. AACC International. Approved Methods of Analysis, 10th ed.; American Association of Cereal Chemists: St Paul, MN, USA, 2000.

43. UNI. UNI Method No. 10690. Durum Wheat and Semolina. Determination of Gluten Quality. Gluten Index Method; UNI: Milan, Italy, 1979.

44. ISO. ISO 3093:2009. Wheat, Rye and Their Flours, Durum Wheat and Durum Wheat Semolina. Determination of the Falling Number according to Hagberg-Perten; ISO: Geneva, Switzerland, 2009.

45. AOAC. Official Methods of Analysis, 17th ed.; The Association of Official Analytical Chemists: Gaithersburg, MD, USA, 2000.

46. Lefebvre, D.; Gabriel, V.; Vayssier, Y.; Fontagne'-Faucher, C. Simultaneous HPLC determination of sugars, organic acids and ethanol in sourdough process. Lebensm.-Wiss. u.-Technol. 2002, 35, 407-414. [CrossRef]

47. Lanza, C.M.; Mazzaglia, A.; Scacco, A.; Pecorino, B. Changes in sensory and instrumental features of industrial Sicilian bread during storage. Ital. J. Food Sci. 2011, 23, 6-12.

48. UNI EN ISO 8586:2014. Sensory Analysis. General Guidelines for the Selection, Training and Monitoring of Selected Assessors and Expert Sensory Assessors; UNI, Ente Nazionale Italiano di Unificazione: Milano, Italy, 2012.

49. Raffo, A.; Pasqualone, A.; Sinesio, F.; Paoletti, F.; Quaglia, G.; Simeone, R. Influence of durum wheat cultivar on the sensory profile and staling rate of Altamura bread. Eur. Food Res. Technol. 2003, 218, 49-55. [CrossRef]

50. Spina, A.; Brighina, S.; Muccilli, S.; Mazzaglia, A.; Fabroni, S.; Fallico, B.; Rapisarda, P.; Arena, E. Wholegrain durum wheat bread fortified with citrus fibers: Evaluation of quality parameters during long storage. Front. Nutr. 2019, 6, 13. [CrossRef]

51. Ficco, D.B.M.; Muccilli, S.; Padalino, L.; Giannone, V.; Lecce, L.; Giovanniello, V.; Del Nobile, M.A.; De Vita, P.; Spina, A. Durum wheat breads 'high in fibre'and with reduced in vitro glycaemic response obtained by partial semolina replacement with minor cereals and pulses. J. Food Sci. Technol. 2018, 55, 4458-4467. [CrossRef]

52. UNI EN ISO 8589:2014. Sensory Analysis—General Guidance for the Design of Test Rooms; UNI, Ente Nazionale Italiano di Unificazione: Milano, Italy, 2012. 
53. Hammer, Ø.; Harper, D.A.T.; Ryan, P.D. PAST: Paleontological statistics software package for education and data analysis. Palaeontol. Electron. 2001, 4, 9.

54. D.P.R. 187. Decreto del Presidente Della Repubblica 9 febbraio 2001, n. 187, "Regolamento per la Revisione Della Normativa Sulla Produzione e Commercializzazione di Sfarinati e Paste Alimentari, a Norma dell'articolo 50 Della Legge 22 Febbraio 1994, n. 146"; Gazzetta Ufficiale Della Repubblica Italiana: Roma, Italy, 2001; p. 13.

55. Giannone, V.; Lauro, M.R.; Spina, A.; Pasqualone, A.; Auditore, L.; Puglisi, I.; Puglisi, G. A novel $\alpha$-amylase-lipase formulation as anti-staling agent in durum wheat bread. LWT-Food Sci. Technol. 2016, 65, 381-389. [CrossRef]

56. Siswoyo, T.A.; Tanaka, N.; Morita, N. Effect of lipase combined with alpha-amylase on retrogradation of bread. Food Sci. Technol. Res. 1999, 5, 356-361. [CrossRef]

57. Schmidt, S.J. Water and solids mobility in foods. In Advances in Food and Nutrition Research; Steve, L.T., Ed.; Elsevier Academic Press 525 B Street, Suite 1900: San Diego, CA, USA, 2004; Volume 48, pp. 1-89.

58. Arena, E.; Fallico, B.; Maccarone, E. Thermal damage in blood orange juice: Kinetics of 5-hydroxymethyl-2-furancarboxaldehyde formation. Int. J. Food. Sci. Technol. 2001, 36, 145-151. [CrossRef]

59. Fallico, B.; Zappalà, M.; Arena, E.; Verzera, A. Effect of conditioning on HMF content in unifloral honeys. Food Chem. 2004, 85, 305-313. [CrossRef]

60. Capuano, E.; Fogliano, V. Acrylamide and 5-hydroxymethylfurfural (HMF): A review on metabolism, toxicity, occurrence in food and mitigation strategies. LWT Food Sci. Technol. 2011, 44, 793-810. [CrossRef]

61. Mesias, M.; Delgado-Andrade, C.; Morales, F.J. Process contaminants in battered and breaded foods prepared at public food service establishments. Food Control 2020, 114, 107217. [CrossRef]

62. Abraham, K.; Gürtler, R.; Berg, K.; Heinemeyer, G.; Lampen, A.; Appel, K.E. Toxicology and risk assessment of 5-Hydroxymethylfurfural in food. Mol. Nutr. Food. Res. 2011, 55, 667-678. [CrossRef]

63. Choudhary, A.; Kumar, V.; Kumar, S.; Majid, I.; Aggarwal, P.; Suri, S. 5-Hydroxymethylfurfural (HMF) formation, occurrence and potential health concerns: Recent developments. Toxin Rev. 2020, 1-17. [CrossRef]

64. Rufián-Henares, J.A.; de la Cueva, S.P. Assessment of hydroxymethylfurfural intake in the Spanish diet. Food Addit. Contam. A. 2008, 25, 1306-1312. [CrossRef]

65. Moreau, L.; Bindzus, W.; Hill, S. Influence of salts on starch degradation: Part II-salt classification and caramelisation. Starch-Starke 2011, 63, 676-682. [CrossRef] 